\title{
The Effect of Organizational Culture, Motivation, and Leadership Style on Employee Performance at the Human Resources Development Agency (BPSDM) of Sumatera Utara Province
}

\author{
Sanrof Baskara Exaudi Simanungkalit ${ }^{1}$, Sukaria Sinulingga ${ }^{2}$, Iskandarini ${ }^{2}$ \\ ${ }^{1,2}$ Master of Management Study Program on Postgraduate School of University of Sumatera Utara.
}

Corresponding Author: Sanrof Baskara Exaudi Simanungkalit

DOI: https://doi.org/10.52403/ijrr.20220115

\begin{abstract}
A government agency is an organization that is a group of people specially selected to carry out state duties as a form of service to the masses. This research aims to determine how much influence organizational culture, work motivation, and leadership style have on employee performance as a dependent variable of the Human Resources Development Agency (BPSDM) of Sumatera Utara Province. The research method used is descriptive analysis with a quantitative approach to all employees at BPSDM Sumatera Utara Province, amounting to 85 respondents. The analysis technique used is multiple linear regression with the SPSS program. Based on the calculation results obtained, the organizational culture, motivation, and leadership style partially and simultaneously influence employee performance. Organizational culture variables, work motivation and leadership style together contribute to employee performance $42 \%$, and $58 \%$ other factors that contribute to employee performance. The leadership style variable is the variable with the strongest influence on performance with a coefficient value of 0.255.
\end{abstract}

Keywords: Organizational culture, motivation, leadership style, performance, BPSDM

\section{BACKGROUND}

Civil Servants is one element of the apparatus that has a strategic role in the implementation of general government tasks and national development. Thus, civil servants as organizers of government duties and functions need to continuously improve their competencies so that their performance is optimal. The provision of public services and development requires government officials who have certain qualifications and abilities (BKN, 2013). In line with that, the vision in the context of development in the field of personnel in the future is to prepare civil servants who are professional, able to compete and able to cope with the world's rapid development in various aspects of life so as to improve the quality of service and high performance. This reflects that the management of the state government is highly dependent on the quality of human resources at war. Without civil servants who have competency requirements, a state administration system will fail in carrying out its mission.

The Human Resources Development Agency (BPSDM) is an agency that has the main task of carrying out the supporting functions of government affairs which are the authority of the Provincial Region in the field of Human Resource Development. BPSDM is required to play a role in developing ASN competencies from upstream to downstream. BPSDM does not only organize training and education for the apparatus but also has a function to carry out Standardization, Certification and Competency Development. In accordance 
Sanrof Baskara Exaudi Simanungkalit et.al. The effect of organizational culture, motivation, and leadership style on employee performance at the human resources development agency (BPSDM) of Sumatera Utara Province.

with Law Number 5 of 2014 concerning ASN, competency development is not only through apparatus training but can also be carried out with other efforts, such as: Seminars, Workshops, Upgrading, in-job training, e-7 learning, Benchmarking, and so on (BPK, 2020).

Based on the results of interviews with the head of staffing that the results of employee work behavior are still less than expected due to a lack of motivation and organizational culture within the BPSDM of Sumatera Utara Province, this can be seen in the lack of consistency of employees to complete a job, less obedient in obeying applicable regulations, less able to work together with co-workers. In addition, the leadership factor also influences employee performance. The performance appraisal of Civil Servants is carried out based on the principles of being objective, measurable, accountable, participatory, and transparent. PNS performance appraisal is carried out by an appraiser once a year (end of December of the year concerned) which consists of the Employee Work Target (SKP) element and the work behavior element.

Table 1. Pre-Survey Results of BPSDM Employee Performance Mei 2019 Periode

\begin{tabular}{|c|c|c|c|c|c|c|c|c|c|c|c|c|c|}
\hline \multirow[t]{2}{*}{ No } & \multirow[t]{2}{*}{ Indicator } & \multicolumn{2}{|c|}{ STS 1} & \multicolumn{2}{|c|}{ TS 2} & \multicolumn{2}{|c|}{ KS 3} & \multicolumn{2}{|c|}{ S 4} & \multicolumn{2}{|c|}{ SS 5} & \multirow[t]{2}{*}{ Score } & \multirow{2}{*}{$\begin{array}{l}\text { Ideal } \\
\text { Score }\end{array}$} \\
\hline & & $\mathrm{F}$ & $\mathrm{N}$ & $\mathrm{F}$ & $\mathrm{N}$ & $\mathrm{F}$ & $\mathrm{N}$ & $\mathrm{F}$ & $\mathrm{N}$ & $\mathrm{F}$ & $\mathrm{N}$ & & \\
\hline 1 & Leadership & 18 & 18 & 32 & 64 & 35 & 105 & 45 & 180 & 20 & 100 & 467 & 750 \\
\hline 2 & Organizational Culture & 10 & 10 & 36 & 72 & 24 & 72 & 39 & 156 & 41 & 205 & 515 & 750 \\
\hline 3 & Motivation & 19 & 19 & 31 & 64 & 25 & 75 & 44 & 176 & 31 & 155 & 489 & 750 \\
\hline \multirow[t]{2}{*}{4} & Employee Performances & 23 & 23 & 47 & 94 & 28 & 84 & 22 & 88 & 30 & 150 & 439 & 750 \\
\hline & \multicolumn{11}{|c|}{$\begin{array}{c}\text { Total } \\
\text { Averages }\end{array}$} & 1910 & \\
\hline
\end{tabular}

Based on the results of the presurvey, it appears that the average score of employee performance in the Human Resources Development Agency can be said to be not optimal. This indicator is not good because there are still employees who are lacking in completing work with a quality level that exceeds expectations, employees are less able to complete work in a fairly fast period of time, employees are less able to obey the rules in the office, and employees are also less able to cooperate with each other work. In the implementation of optimal performance achievement, more adequate employee competencies are needed and can support all employee activities in completing work both in quality and quantity. To produce a better output or level of achievement, so that the success of an employee's performance can be measured from the competence of the human resources themselves in expressing the results of their good thoughts. This is the perfection of an employee in applying his potential in accordance with his competence for performance appraisal (BKN, 2013).
The inconsistency of employee performance that occurs simply decreases, there are several factors that affect the performance of the employee himself, such as internal factors of every employee in the organization, such as leadership, discipline, motivation, compensation, and competence factors (Siagian, 2003). In addition to internal factors, external factors also certainly have an influence on employee performance, such as the work environment and organizational culture.

Leadership has a huge influence on the running of the organization, because through leadership it will be able to create organizational culture. Problems such as an unresponsive leadership style and the lack of appreciation given by the leadership to employees, which makes employee motivation decrease, in the BPSDM environment a form of appreciation for employees such as the appreciation of Exemplary PNS has never been carried out in the last three years. If this happens, then the person concerned will carry out his work just doing work or even just filling out the attendance list. Organizational culture 
Sanrof Baskara Exaudi Simanungkalit et.al. The effect of organizational culture, motivation, and leadership style on employee performance at the human resources development agency (BPSDM) of Sumatera Utara Province.

problems, such as in carrying out their duties, are expected to be able to overcome various situations that exist in the office.

Employees are expected to know and determine what to do by looking at the ethics and morals that apply in the office, such as employees who leave the office without clear permission, there are even employees who do not return to their rooms, and employees are also not punctual in completing their duties and responsibilities. . There are also some employees who delegate tasks to their colleagues for no apparent reason. This is evidence that some employees do not pay attention to their ethics as employees.

In terms of discipline, especially attendance, there are still many employees who are late or not on time when they come to work, therefore to avoid the occurrence of signature violations/fraud, the government issued a policy on electronic attendance to replace manual attendance that has been running so far.

Regina Luni, David P.E Saerang, and Maria V.J Tielung (2015) investigated the effect of work stress and motivation on work performance (a case study at the South Minahasa secretariat office). This study was designed to determine the effect of work stress and motivation on work performance at the South Minahasa Secretariat Office. The results of this study indicate that there is a significant simultaneous and partial effect on Work Performance at the South Minahasa Secretariat Office

Azis Fathoni, Maria Magdalena Minarsih, Sutrisno (2016) examined the Influence of Work Motivation and Discipline on Employee Performance at the Semarang City Civil Service Police Unit. The purposes of this study are: to determine the partial effect of work motivation on the performance of the Civil Service Police Unit Office of Semarang City, to find out work discipline has a partial effect on the performance of the Semarang City Civil Service Police Unit's employee's performance, to find out motivation and work discipline have a simultaneous effect on performance employees of the Semarang City Civil Service Police Unit. The results of this study are the motivation at the Semarang City Civil Service Police Unit has a partial effect on performance, based on employee perceptions, work discipline at the Semarang City Civil Service Police Unit has a partial influence on performance, based on employee perceptions and motivation and work discipline has an effect simultaneously on employee performance.

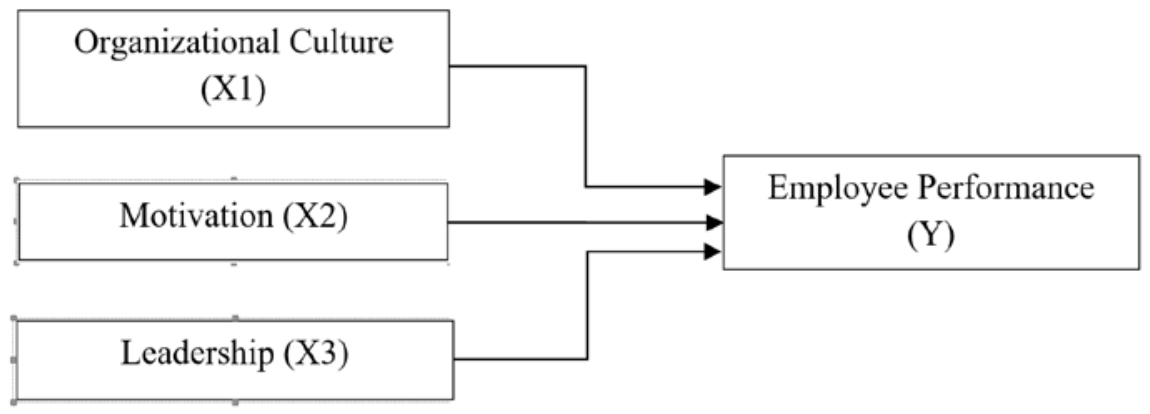

Figure 1. Conceptual Framework

\section{Hypotheses}

1. Organizational Culture has a significant effect on employee performance at the Human Resources Development Agency (BPSDM) of Sumatera Utara Province.

2. Motivation has a significant influence on employee performance at the Human
Resources Development Agency (BPSDM) of Sumatera Utara Province.

3. Leadership style has a significant influence on employee performance in the Human Resources Development Agency (BPSDM) of Sumatera Utara Province. 
Sanrof Baskara Exaudi Simanungkalit et.al. The effect of organizational culture, motivation, and leadership style on employee performance at the human resources development agency (BPSDM) of Sumatera Utara Province.

4. Organizational culture, motivation and leadership style have a partial or simultaneous influence on employee performance at the Human Resources Development Agency (BPSDM) of Sumatera Utara Province.

\section{RESEARCH METHOD}

This research is a causal explanatory relationship in the form of a survey that aims to determine the pattern of causal relationships between the variables of Organizational Culture, Motivation, Leadership Style and Employee Performance. The research design is a guideline that contains the steps that must be followed by researchers to conduct their research. The research design must be made systematically and logically so that it can be used as a guide that is really followed. In this study, the population of the BPSDM Province of Sumatera Utara was 85 people. Because the population is less than 100 people, the entire population can be sampled. Thus, the sampling technique is "Total sampling". So the number of samples in this study were 85 people. The types of data used in this study include two types of data, namely primary data and secondary data. First, primary data is data obtained or collected directly in the field by the person conducting the research or the person concerned who needs it. In this study, data collection was carried out by distributing 85 questionnaires to be distributed to civil servants at the BPSDM of Sumatera Utara Province. The questionnaire is divided into two parts, the first is related to the characteristics of the respondents based on demographic segmentation, such as gender, age. The second part lists the variables of Organizational Culture, Motivation, and Leadership Style, and Employee Performance.

Secondary data is data obtained indirectly from the object of research. Secondary data is data that is not obtained from the source directly, but has been collected by other parties. This data is taken through literature review from books, journals or from other research related to the theme of this research.

The approach used in this research is a quantitative approach. Multiple regression analysis was used to determine whether there was a significant effect of the dependent variable or more than one independent variable. The dependent variable in this study is the Performance of BPSDM Employees of Sumatera Utara Province. While the independent variables in this study are organizational culture, motivation, leadership style.

\section{RESULT AND DISCUSS Validity and Reliability Test}

The validity test tested each of the variables used in this study. All research variables contain 20 statements that must be answered by respondents. Respondents in the validity test were 30 employees of the Regional Personnel Agency (BKD) of Sumatera Utara Province (outside the research sample).

\begin{tabular}{|c|c|c|c|c|}
\hline Variable & Questions & Ixy & $r$ table & Validity \\
\hline \multirow{5}{*}{$\begin{array}{l}\text { Organizational } \\
\text { Culture }\end{array}$} & 1 & 0,776 & 0,361 & Valid \\
\hline & 2 & 0,860 & 0,361 & Valid \\
\hline & 3 & 0,764 & 0,361 & Valid \\
\hline & 4 & 0,709 & 0,361 & Valid \\
\hline & 5 & 0,672 & 0,361 & Valid \\
\hline \multirow{5}{*}{ Motivation } & 1 & 0,748 & 0,361 & Valid \\
\hline & 2 & 0,664 & 0,361 & Valid \\
\hline & 3 & 0,751 & 0,361 & Valid \\
\hline & 4 & 0,545 & 0,361 & Valid \\
\hline & 5 & 0,797 & 0,361 & Valid \\
\hline \multirow{5}{*}{ Leadership Style } & 1 & 0,825 & 0,361 & Valid \\
\hline & 2 & 0.811 & 0,361 & Valid \\
\hline & 3 & 0,749 & 0,361 & Valid \\
\hline & 4 & 0,759 & 0,361 & Valid \\
\hline & 5 & 0,727 & 0,361 & Valid \\
\hline \multirow{5}{*}{$\begin{array}{l}\text { Employee } \\
\text { Performance }\end{array}$} & 1 & 0,764 & 0,361 & Valid \\
\hline & 2 & 0,654 & 0,361 & Valid \\
\hline & 3 & 0,737 & 0,361 & Valid \\
\hline & 4 & 0,701 & 0,361 & Valid \\
\hline & 5 & 0,534 & 0,361 & Valid \\
\hline
\end{tabular}

The value of the $r$ count of all tested indicators is positive and greater than the value of $r$ table. So it can be concluded that all indicator items used in this study passed the validity test and were declared valid. 
Sanrof Baskara Exaudi Simanungkalit et.al. The effect of organizational culture, motivation, and leadership style on employee performance at the human resources development agency (BPSDM) of Sumatera Utara Province.

Table 3. Reliability Test Result

\begin{tabular}{|c|c|c|c|c|}
\hline No & Variable & $\begin{array}{c}\text { Cronbach's } \\
\text { Alpha }\end{array}$ & CA value & Description \\
\hline 1 & Organizational Culture & 0,814 & 0,60 & Reliable \\
\hline 2 & Motivation & 0,743 & 0,60 & Reliable \\
\hline 3 & Leadership Style & 0,832 & 0,60 & Reliable \\
\hline 4 & Employee Performance & 0,702 & 0,60 & Reliable \\
\hline
\end{tabular}

Alpha coefficient values of the variables studied showed different results. However, all the statement items of the independent variable $(\mathrm{X})$ and the dependent variable $(\mathrm{Y})$ have an Alpha coefficient value greater than 0.60 . Thus it can be concluded that the measuring instrument used in this study is reliable.

\section{Simultaneous Significance Test Results (Statistical Test F)}

Table 4.Simultaneous Significance Test

\begin{tabular}{|l|c|c|c|c|c|c|}
\hline \multicolumn{7}{|c|}{ ANOVA $^{\mathrm{a}}$} \\
\hline \multicolumn{2}{|c|}{ Model } & Sum of Squares & df & Mean Square & F & Sig. \\
\hline \multirow{3}{*}{1} & Regression & 100,183 & 3 & 33,394 & 19,577 &, $000^{b}$ \\
\cline { 2 - 7 } & Residual & 138,170 & 81 & 1,706 & & \\
\cline { 2 - 7 } & Total & 238,353 & 84 & & & \\
\hline \multicolumn{7}{|l|}{ a. Dependent Variable: Performance } \\
\hline \multicolumn{6}{|l|}{ b. Predictors: (Constant), Leadership Style, Organizational Culture, Motivation } \\
\hline
\end{tabular}

Sig value. is 0.000 because the value of sig. $0.000<0.05$, then according to the basis of decision making in the F test, it can be concluded that the hypothesis is accepted in other words Organizational Culture (X1) Motivation (X2) and Leadership Style (X3) simultaneously affect employee performance (Y).

\section{Partial Test (T Test)}

Table 5. Partial Test (T Test)

\begin{tabular}{|c|c|c|c|c|c|c|}
\hline \multicolumn{7}{|c|}{ Coefficients $^{\mathrm{a}}$} \\
\hline \multirow{2}{*}{\multicolumn{2}{|c|}{ Model }} & \multicolumn{2}{|c|}{ Unstandardized Coefficients } & \multirow{2}{*}{$\begin{array}{c}\text { Standardized } \\
\text { Coefficients }\end{array}$} & \multirow[t]{2}{*}{$\mathrm{t}$} & \multirow[t]{2}{*}{ Sig. } \\
\hline & & B & Std. Error & & & \\
\hline \multirow{4}{*}{1} & (Constant) & 5,901 & 2,129 & & 2,771 & ,007 \\
\hline & $\begin{array}{l}\text { Organizational } \\
\text { Culture }\end{array}$ & 223 & 091 & ,255 & 2,453 & ,016 \\
\hline & Motivation &, 253 & 099 &, 267 & 2,548 &, 013 \\
\hline & $\begin{array}{l}\text { Leadership } \\
\text { Style }\end{array}$ & ,255 & 084 & ,290 & 3,027 & ,003 \\
\hline
\end{tabular}

Sig value. all independent variables sig. $0.000<0.05$, then according to the basis of decision making in the $t$ test, it can be concluded that the hypothesis is accepted in other words partially the variables of Organizational Culture (X1), Motivation (X2) and Leadership Style (X3) affect employee performance (Y). 
Sanrof Baskara Exaudi Simanungkalit et.al. The effect of organizational culture, motivation, and leadership style on employee performance at the human resources development agency (BPSDM) of Sumatera Utara Province.

\section{Coefficient of Determination and Coefficient of Correlation}

Table 6. Coefficient of Determination $\left(\mathbf{R}^{2}\right)$

\begin{tabular}{|l|r|r|r|r|}
\hline \multicolumn{5}{|c|}{ Model Summary $^{\mathbf{b}}$} \\
\hline Model & $\mathrm{R}$ & R Square & $\begin{array}{c}\text { Adjusted R } \\
\text { Square }\end{array}$ & $\begin{array}{l}\text { Std. Error of the } \\
\text { Estimate }\end{array}$ \\
\hline 1 &, $648^{\mathrm{a}}$ &, 420 &, 399 & 1,306 \\
\hline $\begin{array}{l}\text { a. Predictors: (Constant), Leadership Style, Motivation, } \\
\text { Organizational Culture }\end{array}$ \\
\hline
\end{tabular}

R Square coefficient of 0.420 . This means that the variables of organizational culture, motivation and leadership style together contribute to employee performance $42 \%$, and $58 \%$ other factors that contribute to employee performance.

\section{Hypothesis Testing (Multiple Linear Regression Analysis)}

Table 7.Hypothesis Testing Result

\begin{tabular}{|c|c|c|c|c|c|c|}
\hline \multicolumn{7}{|c|}{ Coefficients $^{2}$} \\
\hline \multirow{2}{*}{\multicolumn{2}{|c|}{ Model }} & \multicolumn{2}{|c|}{$\begin{array}{l}\text { Unstandardized } \\
\text { Coefficients }\end{array}$} & \multirow{2}{*}{$\begin{array}{c}\text { Standardized } \\
\text { Coefficients } \\
\text { Beta }\end{array}$} & \multirow[t]{2}{*}{$\mathrm{t}$} & \multirow[t]{2}{*}{ Sig. } \\
\hline & & B & Std. Error & & & \\
\hline \multirow{4}{*}{1} & (Constant) & 5,901 & 2,129 & & 2,771 & ,007 \\
\hline & Organizational Culture & ,223 & 091 &, 255 & 2,453 & 016 \\
\hline & Motivation & .253 & .099 & .267 & 2,548 & ,013 \\
\hline & Leadership Style & ,255 & ,084 & ,290 & 3,027 & 003 \\
\hline
\end{tabular}

a. The multiple regression equation above is known to have a constant of 5.901 with a positive sign. So the magnitude of the constant shows that if the independent variables (X1, X2 X3) are assumed to be constant, then the dependent variable, namely the average performance, is 5.901

b. Regression coefficient X1 (Organizational Culture) of 0223 means that each supervision is at the level of one unit, causing an increase in employee performance of 0.223 units.

c. Regression coefficient X2 (motivation) of 0.253 means that each motivation is increased by one unit, causing an increase in employee performance of 0.253 units.

d. Regression coefficient X3 (leadership style) of 0.255 means that each Leadership Style is leveled by one unit, causing an increase in employees of 0.255 units.

\section{CONCLUSION}

1. Organizational culture has a positive and significant effect on employee performance at the Human Resources Development Agency (BPSDM) of Sumatera Utara Province.

2. Motivation has a positive and significant effect on employee performance at the Human Resources Development Agency (BPSDM) of Sumatera Utara Province.

3. Leadership style has a positive and significant effect on employee performance at the Human Resources Development Agency (BPSDM) of Sumatera Utara Province.

4. Based on the F test and T test the value of sig. is 0.000 because the value of sig. $0.000<0.05$, then according to the basis of decision making in the $\mathrm{F}$ test and $\mathrm{T}$ test, it is concluded that the hypothesis is accepted in other words organizational culture, motivation, and leadership style partially and simultaneously affect employee performance at the Human 
Sanrof Baskara Exaudi Simanungkalit et.al. The effect of organizational culture, motivation, and leadership style on employee performance at the human resources development agency (BPSDM) of Sumatera Utara Province.

Resources Development Agency (BPSDM) Sumatera Utara Province.

\section{Acknowledgement: None}

\section{Conflict of Interest: None}

\section{Source of Funding: None}

\section{REFERENCES}

1. A.F.Stoner James, DKK (1996). Manajemen , Edisi Indonesia, Penerbit PT. Prenhallindo, Jakarta.

2. Abraham H. Maslow, 2010, Motivation and Personality. Rajawali, Jakarta

3. Asri Laksmi (2011) Perspektif Kompensasi. Surakarta: Yuma Pustaka

4. Badan Kepegawaian Negara. 2013. Pedoman Penyusunan Standar Kompetensi Manajerial Pegawai Negri Sipil. Jakarta

5. BPK https://peraturan.bpk.go.id/Home/Details/ 38685/uu-no-23-tahun-2014. Diakses pada tanggal 2 November 2020

6. Chatman, Jennifer and Bersade. (1997). Employee Satisfaction, Factor Associated. With Company Performance. Journal of Applied Psychology

7. David (2004). Manajemen Strategi Konsep-Konsep. Jakarta: PT Indeks Kelompok. Gramedia

8. Daly, Hamlan. (2015). Pengaruh Kompetensi, Disiplin dan Kompensasi Terhadap. Kinerja Pegawai Badan Pemberdayaan Perempuan dan Keluarga

9. Engko, Cecilia., dan Gudono. 2007. Pengaruh Kompleksitas Tugas dan Locus of Control Terhadap Hubungan Antara Gaya Kepemimpinan dan Kepuasan Kerja Auditor. JAAI. Volume 11, No2: Desember.

10. Fathoni Aziz. (2016) Pengaruh Motivasi Dan Disiplin Kerja Terhadap Kinerja Pegawai Di Kantor Satuan Polisi Pamong Praja Kota Semarang

11. Gibson, et all, (1995). Organisasi dan Manajemen, Edisi ke empat, Jakarta : Erlangga

12. Gouzali Saydam. (2005). Manajemen Sumber daya Manusia: Suatu pendekatan. Mikro. Jakarta: Djambaran
13. Jerald Greenberg dan Robert A. Baroon, (2003:190). Prentice Hall, 2003 - Business \& Economics

14. Kreitner dan Kinicki (2003) Perilaku Organisasi, Terjemahan: Erly. Suandy, Edisi Pertama, Penerbit Salemba Empat, Jakarta

15. Lund, D. (2003). Organizational culture and job satisfaction. Journal of Business \& Industrial Marketing

16. Luni, Regina (2015). Pengaruh Stress Kerja Dan Motivasinya Pada Penampilan Kerja (Studi Kasus Di Kantor Sekretariat Minahasa Selatan)

17. Mangkunegara (2005) Manajemen Sumber daya Manusia. Perusahaan. Bandung : PT Remaja Rosdakarya.

18. Mardalis. 2009. Metode Penelitian (Suatu Pendekatan Proposal), Jakarta: Bumi Aksara

19. Mulyadi dan Rivai (2009). Manajemen Sumber Daya Manusia, Jakarta cetakan kesembilan

20. Munandar (2001), Psikologi Industri dan Organisasi. Jakarta : UI.

21. Oemar (2001) Proses Belajar Mengajar. Jakarta : Bumi Aksara

22. Ostroff, C. (1992). The relationship between satisfaction, attitudes, and performance: An organizational level analysis. Journal of Applied Psychology

23. Rivai (2009) Manajemen Sumber Daya Manusia Untuk Perusahaan. Dari Teori ke Praktik. Jakarta: Raja Grafindo Persada

24. Robbins (2008) Perilaku Organisasi, Jilid I dan II, alih Bahasa : Hadyana. Pujaatmaja. Jakarta: Prenhallindo

25. Robert Heller (1998) im Hindle. DK Pub., 1998 - Business \& Economics

26. Sedarmayanti, (2001) Sumber Daya Manusia dan Produktivitas Kerja. Jakarta

27. Sekaran, (2006). Metode Penelitiaan Bisnis. Jakarta: Salemba Empat.

28. Simamora, (2006). Manajemen Sumber Daya Manusia. Yogyakarta: STIE TKPN.

29. Singarimbun, (1995). Metode Penelitian Survey, Jakarta : PT. Pustaka LP3ES.

30. Suharsimi Arikunto (2006) Prosedur Penelitian Suatu Pendekatan Praktik, Jakarta: Rineka Cipta 
Sanrof Baskara Exaudi Simanungkalit et.al. The effect of organizational culture, motivation, and leadership style on employee performance at the human resources development agency (BPSDM) of Sumatera Utara Province.

31. Sugiyono. 2013. Metode Penelitian How to cite this article: Sanrof Baskara Kuantitatif, Kualitatif, dan R\&D. Exaudi Simanungkalit, Sukaria Sinulingga, Bandung CV Alfabet Iskandarini. The effect of organizational 32. Suliyanto, (2005) Metode Riset Bisnis. culture, motivation, and leadership style on Yogyakarta employee performance at the human resources development agency (BPSDM) of Sumatera Utara Province. International Journal of Research and Review. 2022; 9(1): 100-107. DOI: https://doi.org/10.52403/ijrr.20220115 